\begin{tabular}{l|l}
\hline Cotaice & $\begin{array}{l}\text { e-ISSN: 2655-9404 p-ISSN: 2721-8376 } \\
\text { Vol. 4 No. 2, Juni 2021 }\end{array}$ \\
\hline
\end{tabular}

Article history: Submitted 27 March 2021; Accepted 5 April 2021; Available online 1 June 2021.

\title{
Wanprestasi pada Kredit Perbankan Akibat Pandemi Coronavirus Disease 2019
}

\author{
Olga Nadina \\ olganadin.on@gmail.com \\ Universitas Airlangga
}

\begin{abstract}
This research discusses the concept of default on bank credit due to the Coronavirus Disease 2019 (Covid-19) pandemic. In order to maintain the national economic growth which is decreasing due to the Covid-19 pandemic, POJK No. 11/2020 juncto POJK No. 48/2020 regulates the provision of stimulus policies for bank debtors who experience difficulties in fulfilling their obligations to banks. After the enactment of this policy, the debtor is declared to be in default if there is an arrear that exceeds 90 days because the debtor does not meet the requirements for the accuracy of principal and/ or interest payments in Article 3 paragraph (1) POJK No. 11/2020 juncto POJK No. 48/2020, so that debtor credit cannot be restructured. Due to the unsuccessful restructuring, based on Article 5 paragraph (1) POJK No. 11/2020 juncto POJK No. 48/2020, the credit quality remains in the nonperforming loan category. The legal measures that can be taken by banks are through the efforts to save credit by credit restructuring. This study taken an example of a restructuring scheme at BRI Bank, by using the method of lowering interest rates, changes in principal installment scheduling and extension of the credit period. If the loan restructuring is not successful, then the bank needs to handle it by credit settlement efforts.

Keywords: Default; Bank Credits; Covid-19.
\end{abstract}

\begin{abstract}
Abstrak
Penelitian ini membahas mengenai wanprestasi pada kredit perbankan akibat pandemi Coronavirus Disease 2019 (Covid-19). Untuk menjaga pertumbuhan perekonomian nasional yang sedang menurun akibat pandemi Covid-19, diterbitkan POJK No. 11/2020 juncto POJK No. 48/2020 yang mengatur mengenai pemberian kebijakan stimulus bagi debitur bank yang mengalami kesulitan untuk memenuhi kewajibannya kepada bank. Pasca berlakunya kebijakan tersebut, debitur dinyatakan melakukan wanprestasi apabila, terjadi tunggakan yang melebihi 90 hari dikarenakan debitur tersebut tidak memenuhi persyaratan ketepatan pembayaran pokok dan/atau bunga dalam Pasal 3 ayat (1) POJK No. 11/2020 juncto POJK No. 48/2020, sehingga kredit debitur tidak dapat dilakukan restrukturisasi. Oleh karena tidak berhasil direstrukturisasi, berdasarkan Pasal 5 ayat (1) POJK No. 11/2020 juncto POJK No. 48/2020 maka kualitas kredit tetap dalam kategori kredit bermasalah. Upaya penanganan yang dapat dilakukan bank yaitu melalui upaya penyelamatan kredit dengan melakukan restrukturisasi kredit. Penelitian ini mengambil contoh skema restrukturisasi pada Bank BRI, yaitu dengan menggunakan metode penurunan suku bunga, perubahan penjadwalan angsuran pokok dan perpanjangan jangka waktu kredit. Jika restrukturisasi kredit tidak berhasil, maka dilakukan upaya penanganan melalui upaya penyelesaian kredit.
\end{abstract}

Kata Kunci: Wanprestasi; Kredit Perbankan; Covid-19. 


\section{Pendahuluan}

Pada awal tahun 2020, dunia sedang dilanda oleh wabah Coronavirus Disease 2019 (selanjutnya disebut dengan Covid-19) yang penyebarannya menjadi tidak terkendali. Tak luput dari itu, sejak awal Maret 2020 pandemi Covid-19 telah memasuki wilayah Indonesia. ${ }^{1}$ Pandemi Covid-19 memberikan dampak besar pada seluruh sektor kehidupan masyarakat. Selain dampaknya di bidang kesehatan, sektor ekonomi merupakan salah satu yang paling besar merasakan dampak dari pandemi ini.

Sebagai upaya untuk menahan laju penyebaran Covid-19, pemerintah menciptakan kebijakan Pembatasan Sosial Berskala Besar. Selama kebijakan tersebut berlangsung hampir seluruh aktivitas masyarakat berhenti dan akibatnya berdampak besar pada kinerja ekonomi. Ketua Tim Penanganan Covid-19 dan Pemulihan Ekonomi Nasional, Airlangga Hartarto menjelaskan terjadi kontraksi terhadap perekonomian Indonesia dan pertumbuhan berkurang sebesar 5,32 persen. ${ }^{2}$ Bank Indonesia memberikan prediksi bahwa pertumbuhan ekonomi Indonesia pada tahun ini akan tertekan di level 2,1 persen, sedangkan dalam kondisi normal mampu tumbuh mencapai 5,02 persen. ${ }^{3}$ Dikarenakan terjadi penurunan pertumbuhan ekonomi, hal tersebut berimbas pula bagi sektor perbankan. Menurut data OJK sejak Maret 2020, terjadi peningkatan jumlah kredit bermasalah. Golongan debitur yang sudah menunggak minimal 1-2 bulan (Kredit Kol-2) naik tajam menjadi 27,3 persen secara year on year. Jumlah golongan kredit tidak lancar (Kol-3) dan golongan kredit macet (Kol-5) mengalami kenaikan sebesar 19,10 persen. ${ }^{4}$

${ }^{1}$ Niken Widya Yunita, 'Penyebab, Asal Mula Dan Pencegahan Virus Corona Di Indonesia' (News Detik, 2020) <https:/ / news.detik.com/ berita/d-4956764/ penyebab-asal-mula-dan-pencegahan-viruscorona-di-indonesia> accessed 13 September 2020.

${ }^{2}$ Pipit Ika Ramadhani, ‘Jakarta PSBB Lagi, Simak Dampaknya Terhadap Ekonomi' (Liputan 6, 2020) <https://sukabumiupdate.com/posts/67504/dampak-pandemi-corona-terhadap-sektorekonomi-indonesia> accessed 13 September 2020.

${ }^{3}$ Nabila Nurul Putri, 'Dampak Pandemi Corona Terhadap Sektor Ekonomi Indonesia' (Sukabumi Update, 2020) <https://sukabumiupdate.com/posts/67504/dampak-pandemi-coronaterhadap-sektor-ekonomi-indonesia> accessed 13 September 2020.

${ }^{4}$ Vincent Fabian Thomas, 'Efek Corona Pada Perbankan: Kredit Dikurangi, Cabang Tutup Temporer' (Tirto Id, 2020) <https:/ / tirto.id/ efek-corona-pada-perbankan-kredit-dikurangi-cabangtutup-temporer-fDpN> accessed 13 September 2020. 
Dalam kegiatan penyaluran kredit, tidak dapat dipungkiri, bank harus siap menghadapi risiko kredit yang menyebabkan kredit tersebut menjadi bemasalah. Peningkatan kredit bermasalah yang dialami perbankan nasional mengakibatkan bank kehilangan kemampuannya untuk menghasilkan laba yang optimum dari kegiatan operasional bank. Dana operasional bank diputar dalam bentuk kredit. Namun, akibat penyebaran Covid-19jumlah kredit bermasalah meningkat. Dengan adanya kredit yang bermasalah tidak hanya menurunkan pendapatan bank, tetapi juga dapat mempengaruhi jumlah dana operasional dan likuiditas keuangan bank, sehingga mengganggu kesehatan bank dan akhirnya berujung pada kerugian nasabah penyimpan dana. ${ }^{5}$ Agar dapat bertahan, bank harus mempertahankan tingkat profitabilitas serta tingkat likuiditas bank. Kedua hal tersebut terkait dengan kemampuan bank untuk menjalankan kewajibannya kepada para pihak yang sewaktu-waktu berkehendak untuk mencairkan atau menarik simpanannya, hal ini ditujukan agar bank tersebut dapat menjaga kepercayaan dari masyarakat. ${ }^{6}$

Sebagai upaya agar bank selalu dalam keadaan sehat, liquid, solvent dan profitable, Otoritas Jasa Keuangan menerbitkan POJK Nomor 11/POJK.03/2020 sebagaimana telah diubah dengan POJK Nomor 48/POJK.03/2020 Tentang Perubahan Atas Peraturan Otoritas Jasa Keuangan Nomor 11/POJK.03/2020 Tentang Stimulus Perekonomian Nasional Sebagai Kebijakan Countercyclical Dampak Penyebaran Coronavirus Disease 2019 (selanjutnya disingkat POJK No. 11/2020 juncto POJK No. 48/2020). Setelah terbitnya POJK No. 11/2020 juncto POJK No. 48/2020 tersebut terdapat suatu isu hukum yang dapat dibahas, yaitu terjadi perubahan terhadap kriteria wanprestasi dalam kredit perbankan.

C. Asser berpendapat bahwa ciri utama perikatan adalah hubungan hukum antara para pihak, kemudian dalam hubungan itu terdapat hak (prestasi) dan kewajiban (kontra prestasi). Para pihak dalam perikatan, yaitu kreditur dan debitur disebut sebagai subyek perikatan. Kreditur disebut sebagai pihak yang aktif, yaitu

${ }^{5}$ Trisadini dan Abdul Shomad, Hukum Perbankan (Kencana Prenanda Media 2017).[121].

${ }^{6}$ Eka Fitri Handayani dan A. Zubaidi, 'Pengaruh Kredit Bermasalah Terhadap Tingkat Profitabilitas Dan Likuiditas Pada Industri Perbankan Yang Terdaftar Di Bursa Efek Indonesia' (2014) 19 Jurnal Akuntansi dan Keuangan.[106]. 
pihak yang berhak atas terlaksananya suatu prestasi. Sedangkan debitur sebagai pihak yang pasif, yaitu pihak yang berkewajiban memenuhi suatu prestasi. Sebagai pihak yang aktif kreditur dapat melakukan tindakan-tindakan tertentu terhadap debitur yang tidak memenuhi kewajibannya. Dalam hukum perikatan, kewajiban memenuhi prestasi harus dipenuhi oleh debitur. Oleh karena, jika debitur tidak memenuhi sesuatu yang diwajibkan seperti yang telah ditetapkan dalam perjanjian, maka dikatakan debitur telah melakukan wanprestasi. ${ }^{7}$

Akan tetapi, wanprestasi menurut hukum perikatan dan wanprestasi menurut hukum perbankan diatur dalam ketentuan yang berbeda. Dalam hukum perikatan, wanprestasi diatur dalam Pasal 1243 BW yang diuraikan sebagai berikut:

"Penggantian biaya, rugi dan bunga karena tak dipenuhinya suatu perikatan, barulah mulai diwajibkan, apabila si berutang, setelah dinyatakan lalai memenuhi perikatannya, tetap melalaikannya, atau jika sesuatu yang harus diberikan atau dibuatnya, hanya dapat diberikan atau dibuat dalam tenggang waktu yang telah dilampauinya."

Sedangkan, menurut hukum perbankan sebagaimana diatur dalam Peraturan Otoritas Jasa Keuangan Nomor 40/POJK.03/2019 tentang Penilaian Kualitas Aset Bank Umum (selanjutnya disebut dengan POJK 40/2019). Pasal 30 ayat (2) menyatakan bahwa debitur wanprestasi dalam hal:

a. memiliki tunggakan pokok, bunga dan/atau tagihan lain selama 90 hari walaupun Aset Produktif belum jatuh tempo;

b. tidak melakukan pembayaran pokok, bunga dan/atau tagihan lain pada saat Aset Produktif jatuh tempo; atau

c. tidak memenuhi persyaratan lain selain pembayaran pokok dan/atau bunga yang dapat mengakibatkan terjadi wanprestasi.

Berdasarkan ketentuan Pasal 30 ayat (2) POJK 40/2019 tersebut, maka pemaknaan konsep wanprestasi dalam hukum perbankan yaitu ketika kredit seorang nasabah ditetapkan dalam kategori kredit bermasalah, yaitu kredit yang termasuk dalam kategori kualitas kurang lancar, diragukan dan macet. ${ }^{8}$ Setelah

\footnotetext{
${ }^{7}$ Purwahid Patrik, Dasar-Dasar Hukum Perikatan (Mandar Maju 1994).[2].

${ }^{8}$ Trisadini dan Abdul Shomad (n 5). Op.Cit.[199].
} 
berlakunya POJK No. 11/2020 juncto POJK No. 48/2020, dijelaskan dalam Pasal 2 ayat (1) dan ayat (2) bahwa Bank dapat menerapkan kebijakan yang mendukung stimulus pertumbuhan ekonomi untuk debitur terdampak Covid-19 dengan cara melakukan kebijakan penetapan kualitas aset dan kebijakan restrukturisasi kredit atau pembiayaan. Kemudian, Pasal 5 ayat (1) POJK No. 11/2020 juncto POJK No. 48/2020 menerangkan bahwa kualitas kredit atau pembiayaan yang direstrukturisasi ditetapkan lancar sejak dilakukan restrukturisasi.

Berdasarkan latar belakang yang telah diuraikan di atas, perlu dilakukan pembahasan lebih lanjut terkait kriteria wanprestasi kredit yang dilakukan oleh debitur bank yang terdampak Covid-19 dan pembahasan terkait upaya hukum yang dapat dilakukan oleh bank terhadap debitur dengan kredit bermasalah tersebut setelah terbitnya POJK No. 11/2020 juncto POJK No. 48/2020 dalam suatu penelitian hukum.

\section{Karakteristik Perjanjian Kredit Perbankan}

Istilah kredit berasal dari bahasa Latin "credere" yang berarti kepercayaan. Dalam bahasa Belanda disebut dengan "vertrouwen" yang artinya percaya. 9 Berdasarkan ketentuan Pasal 1 angka 11 UU Perbankan menjelaskan bahwa yang dimaksud dengan kredit adalah penyediaan uang atau tagihan yang dapat dipersamakan dengan itu, berdasarkan persetujuan atau kesepakatan pinjam meminjam antara bank dan pihak lain yang mewajibkan pihak peminjam untuk melunasi hutangnya setelah jangka waktu tertentu dengan jumlah bunga.

Pada saat membentuk perjanjian kredit, terdapat 2 (dua) jenis perjanjian. Perjanjian kredit merupakan perjanjian pokok (principal), kemudian pada umumnya bank mewajibkan agar perjanjian kredit tersebut dibebankan dengan jaminan, contohnya hak tanggungan dengan pihak debitor. Perjanjian jaminan disini adalah sebagai perjanjian tambahan (accessoir), berakhirnya perjanjian jaminan bergantung pada perjanjian pokoknya. ${ }^{10}$

\footnotetext{
${ }^{9}$ Rachmadi Usman, Aspek-Aspek Hukum Perbankan Indonesia (Gramedia Pustaka Utama 2001).[236].

${ }^{10}$ Hermansyah, Hukum Perbankan Nasional Indonesia (Prenadamedia Grup 2014).[71].
} 
Terkait dengan karakter dari perjanjian kredit, Sutan Remy Sjahdeini menyatakan bahwa perjanjian kredit bank memiliki 3 (tiga) ciri yang berbeda dari perjanjian pinjam meminjam dalam Pasal 1754 BW. Ciri pertama adalah perjanjian kredit bersifat konsensual, berbeda dengan perjanjian pinjam meminjam yang bersifat riil. Setelah perjanjian kredit ditandatangani oleh kedua pihak, debitur belum dapat melakukan penarikan kredit dan bank tidak wajib untuk menyediakan dana. Bank dapat memenuhi kewajibannya untuk memberikan kredit dan debitur berhak untuk menarik dana, selama semua persyaratan yang ditentukan dalam perjanjian kredit terpenuhi. Ciri kedua, yaitu debitur tidak dapat menggunakan kredit yang diberikan oleh bank secara leluasa untuk memenuhi kebutuhan pribadi debitur, tetapi harus digunakan sesuai dengan tujuan yang telah ditetapkan dalam perjanjian kredit. Ciri ketiga, yaitu dalam perjanjian pinjam meminjam debitur dan kreditur dapat dengan bebas menentukan cara penggunaan uang pinjaman, namun kredit bank hanya dapat menggunakan metode yang ditentukan oleh bank, seperti cek atau pemindahbukuan. ${ }^{11}$

Berdasarkan ciri tersebut, Sutan Remy Sjahdeini memberikan definisi perjanjian kredit perbankan sebagai perjanjian antara bank (sebagai kreditur) dan nasabah (sebagai debitur) untuk memberikan uang atau tagihan yang setara, yang mewajibkan nasabah (sebagai debitur) untuk melunasi utangnya setelah jangka waktu yang ditentukan dengan membayar kompensasi bunga dan bagi hasil keuntungan. ${ }^{12}$ Dari uraian tersebut di atas, menurut Thomas Suyatno dalam Djumhana dapat disimpulkan bahwa dari kegiatan kredit terdapat unsur-unsur sebagai berikut: ${ }^{13}$

1. Kepercayaan, yaitu keyakinan dari si pemberi kredit bahwa prestasi yang diberikan berupa dana, akan diterima kembali dalam jangka waktu tertentu pada tanggal yang sudah disepakati.

2. Tenggang waktu, yaitu suatu masa yang memisahkan antara pemberian prestasi dan kontraprestasi yang akan diterima di kemudian hari.

${ }^{11}$ Sutan Remi Sjahdeini, Kebebasan Berkontrak Dan Perlindungan Yang Seimbang Bagi Para Pihak Dalam Perjanjian Kredit Bank Di Indonesia (Institut Bankir Indonesia 1994).[160].

${ }^{12}$ Mariam Darus Badrulzaman, Perjanjian Kredit Bank (Citra Aditya Bakti 2008).[38].

${ }^{13}$ Muhamad Djumhana, Hukum Perbankan Di Indonesia (Citra Aditya Bakti 2018).[427]. 
3. Degree of risk, yaitu tingkat risiko yang dihadapi sebagai akibat adanya jangka waktu yang memisahkan antara pemberian prestasi dan kontraprestasi yang akan diterima kemudian hari. Semakin lama kredit diberikan, semakin tinggi pula tingkat risikonya.

4. Prestasi, dalam kehidupan ekonomi masyarakat saat ini, pada praktik perbankan, prestasi dalam kredit pada umumnya berupa uang.

Unsur utama dalam kredit yaitu kepercayaan, sedangkan unsur lainnya bersifat sebagai sesuatu yang dapat membantu untuk memberikan pertimbangan secara menyeluruh dalam mendapatkan atau memperoleh keyakinan untuk terciptanya suatu hubungan hukum ketika pemberian kredit dilakukan. ${ }^{14}$

Perjanjian kredit wajib dituangkan dalam bentuk tertulis. Hal ini tercantum dalam Penjelasan Pasal 8 ayat (2) huruf a. UU Perbankan yang menyatakan bahwa pemberian kredit atau pembiayaan berdasarkan Prinsip Syariah dibuat dalam bentuk tertulis. Hal ini ditegaskan pula dalam Lampiran Peraturan Otoritas Jasa Keuangan Nomor 42/POJK.03/2017 Tentang Kewajiban Penyusunan Dan Pelaksanaan Kebijakan Perkreditan Atau Pembiayaan Bank Bagi Bank Umum dalam BAB IV huruf F. yang mengatur sebagai berikut:

Setiap kredit atau pembiayaan yang telah disetujui oleh pemohon Kredit atau Pembiayaan harus ditulis dalam perjanjian kredit atau pembiayaan (akad Kredit atau Pembiayaan). Bentuk dan format perjanjian Kredit atau Pembiayaan ditentukan oleh masing-masing bank, dan sekurang-kurangnya memenuhi ketentuan sebagai berikut:

1. Memenuhi legalitas dan persyaratan hukum yang dapat melindungi kepentingan bank; dan

2. Mencantumkan jumlah, batas waktu, prosedur pembayaran kembali dan persyaratan kredit atau pembiayaan lainnya yang ditentukan dalam keputusan persetujuan Kredit atau Pembiayaan.

Perjanjian kredit perbankan dalam praktiknya menggunakan bentuk perjanjian baku (standard contract). Pihak bank sebagai kreditur pada umumnya telah menyediakan format perjanjian kredit sedangkan calon debitur hanya dalam posisi menerima atau menolak ketentuan yang dalam perjanjian tersebut

\footnotetext{
${ }^{14}$ ibid.[426].
} 
tanpa diberikan kesempatan untuk melakukan negosiasi atau tawar menawar. Sehingga, apabila debitur tidak menerima semua ketentuan dan persyaratan yang ditentukan oleh bank, maka ia tidak akan mendapatkan fasilitas kredit tersebut. ${ }^{15}$

\section{Wanprestasi Berdasarkan Burgerlijk Wetboek}

Wanprestasi berasal dari bahasa Belanda "wanprestastie", yang artinya buruk. Wanprestasi dapat diartikan tidak dipenuhinya prestasi atau kewajiban yang ditetapkan untuk pihak-pihak tertentu di dalam suatu perikatan. Menurut Kamus Hukum dalam Yahya Harahap, wanprestasi berarti kelalaian, kealpaan, cidera janji, tidak menepati kewajibannya dalam perjanjian. ${ }^{16}$ Pasal 1243 BW menguraikan Wanprestasi sebagai berikut:

"Penggantian biaya, rugi dan bunga karena tak dipenuhinya suatu perikatan, barulah mulai diwajibkan, apabila si berutang, setelah dinyatakan lalai memenuhi perikatannya, tetap melalaikannya, atau jika sesuatu yang harus diberikan atau dibuatnya, hanya dapat diberikan atau dibuat dalam tenggang waktu yang telah dilampauinya".

Pelanggaran hak-hak kontraktual apabila terjadi wanprestasi menimbulkan kewajiban ganti rugi, debitur dinyatakan lalai yaitu ketika: ${ }^{17}$

1. Tidak memenuhi prestasi;

2. Terlambat berprestasi;

3. Berprestasi tetapi tidak sebagaimana yang diperjanjikan;

4. Melakukan perbuatan yang dilarang dalam perjanjian.

Adapun syarat-syarat yang harus dipenuhi untuk dapat dikatakan wanprestasi adalah sebagai berikut: ${ }^{18}$

a. Syarat Materiil, yaitu berupa terjadinya kesalahan dari pihak debitur.

b. Syarat Formil, yaitu berupa peringatan (somasi) dari kreditur kepada debitur, agar debitur segera atau pada waktu tertentu yang ditentukan untuk dapat memenuhi prestasinya.

\footnotetext{
${ }^{15}$ Dyah Kusumaningrum, 'Pelaksanaan Perjanjian Kredit Yang Diikat Dengan Jaminan Fidusia Di PT. Bank Eksekutif Internasional, Tbk. Cabang Semarang' (Universitas Diponegoro 2008).[31].

${ }^{16}$ Yahya Harahap, Segi-Segi Hukum Perjanjian (Alumni 1982).[60].

${ }^{17}$ R. Setiawan, Pokok-Pokok Hukum Perikatan (Binacipta 1979).[18].

18 ibid.
} 
Mengenai syarat formil yaitu somasi, pada umumnya wanprestasi terjadi setelah adanya pernyataan lalai (in mora stelling; ingebreke stelling) dari pihak kreditur kepada debitur. Pada dasarnya, pernyataan lalai tersebut bertujuan untuk menetapkan tenggang waktu yang wajar kepada debitur untuk memenuhi prestasinya dengan sanksi tanggung gugat atas kerugian yang dialami kreditur. ${ }^{19}$ Peringatan (somatie) menurut Pasal 1238 BW, diterbitkan oleh kreditur mengenai lalainya debitur dan harus dituangkan dalam bentuk tertulis. Untuk sampai pada fase debitur dinyatakan wanprestasi, maka harus melalui lembaga pernyataan lalai tersebut sebagai upaya hukum. Namun, terdapat keadaan tertentu yang tidak memerlukan pernyataan lalai untuk membuktikan adanya wanprestasi debitur, antara lain: ${ }^{20}$

a. untuk pemenuhan prestasi berlaku tenggang waktu yang fatal (fatale termijn);

b. debitur menolak pemenuhan;

c. debitur mengakui kelalaiannya;

d. pemenuhan prestasi tidak mungkin (di luar overmacht);

e. pemenuhan tidak lagi berarti (zinloos); dan

f. debitur melakukan prestasi tidak sebagaimana mestinya.

Dalam praktik penyusunan kontrak sering kali dicantumkan klausul yang isinya sesuai dengan uraian tersebut di atas. Apabila tidak dipenuhi salah satu kewajiban debitur dalam kontrak, maka akan dianggap telah terjadi wanprestasi. Sebagai tindak lanjut kondisi ini, diberikan juga klausul pemutusan kontrak sebagai salah satu bentuk sanksi yang dapat dilakukan pihak kreditur.

\section{Wanprestasi Berdasarkan POJK Nomor 40/POJK.03/2019}

Terkait dengan penyaluran dana masyarakat, lembaga bank bergerak dalam kegiatan perkreditan serta berbagai jasa lainnya untuk melayani kebutuhan pembiayaan. Peran tersebut mencerminkan aktivitas-aktivitas utama dari bank, yaitu pertama, menghimpun dana dari masyarakat. Kedua, memutar dana yang dikelolanya ke dalam berbagai aset produktif, contohnya kredit. Ketiga,

\footnotetext{
${ }^{19}$ ibid.

${ }^{20}$ Agus Yudha Hernoko, Hukum Perjanjian Asas Proporsionalitas dalam Kontrak Komersial (Kencana
} 2010).[262]. 
memberikan jasa layanan pembiayaan dan jasa layanan perbankan lainnya. ${ }^{21}$ Untuk membantu kelancaran aktivitas bank tersebut, pada tanggal 19 Desember 2019, OJK menerbitkan POJK No. 40/2019 tentang Penilaian Kualitas Aset Bank Umum. Keberlangsungan bisnis perbankan sangat bergantung pada kemampuan dan efektivitas bank dalam mengelola risiko kredit dan meminimalkan potensi kerugian. Dalam rangka mengelola risiko kredit dan meminimalkan potensi kerugian, bank wajib menjaga kualitas aset dan mewajibkan cadangan kerugian aset. Hal ini untuk meminimalisir potensi kerugian dari debitur yang bermasalah. ${ }^{22}$

Namun demikian, dalam aktivitas penyaluran kredit sangat dimungkinkan untuk terjadi masalah, salah satunya yaitu terjadi risiko kredit. Bank mengharapkan agar kredit yang diberikan pada debiturnya dapat berjalan lancar sampai kredit tersebut tuntas dibayarkan. Akan tetapi, ada kalanya terjadi kegagalan dari pihak debitur untuk memenuhi kewajiban pembayaran kredit pada bank. Kriteria kegagalan debitur dalam memenuhi kewajiban kepada bank akibat wanprestasi diatur dalam Pasal 30 ayat (2) POJK No. 40/2019 yang menyatakan bahwa debitur wanprestasi dalam hal:

a. memiliki tunggakan pokok, bunga dan/atau tagihan lain selama 90 hari walaupun Aset Produktif belum jatuh tempo;

b. tidak melakukan pembayaran pokok, bunga dan/atau tagihan lain pada saat Aset Produktif jatuh tempo; atau

c. tidak memenuhi persyaratan lain selain pembayaran pokok dan/atau bunga yang dapat mengakibatkan terjadi wanprestasi.

Berdasarkan Lampiran POJK No. 40/2019, kualitas kredit berdasarkan ketepatan pembayaran ditentukan sebagai berikut:

a. Kualitas kredit lancar adalah kredit yang pembayarannya tepat waktu, perkembangan kredit baik dan tidak ada tunggakan serta sesuai dengan persyaratan kredit.

b. Apabila debitur menunggak kredit selama 90 hari, maka kualitas kredit

\footnotetext{
${ }^{21}$ Trisadini dan Abdul Shomad (n 5).Op.Cit.[177].

${ }^{22}$ Konsideran Peraturan Bank Indonesia Nomor 14/15/PBI/ 2012 Tentang Penilaian Kualitas Aset Bank Umum Nomor 1-3.
} 
termasuk kategori kredit dalam perhatian khusus.

c. Apabila terjadi tunggakan yang melebihi 90 hari sampai dengan 120 hari, kualitas kredit termasuk dalam kategori kredit kurang lancar.

d. Apabila terjadi tunggakan yang melebihi 120 hari sampai dengan 180 hari, kualitas kredit termasuk dalam kategori diragukan.

e. Apabila terjadi tunggakan yang melebihi 180 hari, maka kualitas kredit termasuk dalam kategori macet.

Berdasarkan ketentuan tersebut, debitur dinyatakan wanprestasi dalam hukum perbankan berdasarkan POJK No. 40/2019 adalah debitur dengan kredit yang kualitasnya termasuk dalam kategori, kurang lancar, diragukan dan macet.

\section{Wanprestasi berdasarkan POJK Nomor 11/POJK.03/2020 juncto POJK Nomor 48/POJK.03/2020}

Peningkatan kredit bermasalah akibat pandemi Covid-19 sangat membahayakan kesehatan bank, karena menyebabkan modal bank semakin berkurang. Pada negara berkembang, kemajuan perekonomian sangat bergantung pada bank. Jika perbankan nasional mengalami kemunduran, maka secara tidak langsung pertumbuhan perekonomian nasional juga mengalami penurunan. Sebagai upaya mencegah hal tersebut, OJK telah menerbitkan POJK No. 11/2020 juncto POJK No. 48/2020. Pada POJK tersebut terdapat pengaturan mengenai kebijakan stimulus bagi debitur bank agar dapat menjaga pertumbuhan perekonomian nasional yang sedang menurun akibat pandemi Covid-19. Setelah berlakunya POJK tersebut, terhadap debitur yang mengalami kesulitan pembayaran, akan diberikan kesempatan untuk melakukan restrukturisasi kredit. Oleh karena itu, dalam sub bab pembahasan ini akan dibahas mengenai kriteria debitur yang layak diberikan restrukturisasi kredit, dengan demikian dapat diketahui juga terkait kriteria wanprestasi yang dilakukan oleh debitur bank.

Terdapat kriteria tertentu yang ditetapkan agar debitur dapat memperoleh restrukturisasi kredit. Penjelasan Pasal 2 ayat (1) POJK No. 11/2020 juncto POJK No. 48/2020 menyatakan bahwa yang dimaksud dengan debitur yang terkena dampak penyebaran Covid-19 termasuk debitur usaha mikro, kecil, dan menengah adalah debitur pada sektor ekonomi antara lain pariwisata, 
transportasi, perhotelan, perdagangan, pengolahan, pertanian, dan pertambangan yang mengalami kesulitan untuk memenuhi kewajiban pada Bank karena debitur atau usaha debitur terdampak dari penyebaran Covid-19 baik secara langsung ataupun tidak langsung. Contoh:

1. Debitur yang terkena dampak penutupan jalur transportasi dan pariwisata dari dan ke Tiongkok atau negara lain yang telah terdampak Covid-19 serta travel warning beberapa negara.

2. Debitur yang terkena dampak dari penurunan volume ekspor impor secara signifikan akibat keterkaitan rantai suplai dan perdagangan dengan Tiongkok ataupun negara lain yang telah terdampak Covid-19.

3. Debitur yang terkena dampak terhambatnya proyek pembangunan infrastruktur karena terhentinya pasokan bahan baku, tenaga kerja, dan mesin dari Tiongkok ataupun negara lain yang telah terdampak Covid-19.

Terhadap debitur yang termasuk dalam kriteria tersebut, berdasarkan Pasal 2 ayat (1) dan ayat (2) POJK No.11/2020 juncto POJK No. 48/2020 menyatakan bahwa Bank dapatmenerapkan kebijakan yang mendukung stimulus pertumbuhan ekonomi untuk debitur yang terkena dampak penyebaran Covid-19, meliputi kebijakan penetapan kualitas aset dan kebijakan restrukturisasi kredit.

Dalam suatu peraturan terkadang tidak diatur secara khusus suatu peristiwa tertentu. Terhadap hal tersebut dapat dilakukan penafsiran hukum dengan metode argumentum a contrario. Metode tersebut merupakan cara penafsiran atau menjelaskan ketentuan suatu peraturan yang didasarkan pada pengertian yang berupa kebalikan dari peristiwa yang diatur dalam UU dengan peristiwa konkrit yang dihadapi. ${ }^{23}$

Berdasarkan penafsiran secara a contrario, debitur yang tidak dapat diberikan kebijakan stimulus berupa penilaian kualitas aset dan restrukturisasi kredit adalah debitur yang usahanya tidak terdampak Covid-19. Debitur yang tidak terdampak Covid-19 adalah debitur yang tidak berasal dari sektor

${ }^{23}$ Sudikno Mertokusumo, Mengenal Hukum (Liberty 2007).[180]. 
pariwisata, transportasi, perhotelan, perdagangan, pengolahan, pertanian, dan pertambangan. Termasuk juga, debitur yang tidak terkena dampak penutupan jalur transportasi dan pariwisata dari Tiongkok atau negara lain, debitur yang tidak mengalami penurunan volume ekspor impor secara signifikan akibat Covid-19 dan debitur yang proyek pembangunan infrastrukturnya tidak mengalami hambatan akibat Covid-19. Sehingga, untuk debitur yang tidak terdampak Covid-19, maka tidak dapat diberikan kebijakan stimulus oleh bank. Terhadap debitur tersebut, apabila tidak melakukan pembayaran kredit selama 90 hari, berdasarkan Pasal 30 ayat (2) POJK No. 40/2019, debitur tersebut dapat dikatakan telah melakukan perbuatan wanprestasi.

Ketentuan pada POJK No. 11/2020 juncto POJK No. 48/2020 mengatur bahwa salah satu kebijakan stimulus adalah penetapan kualitas aset. Dalam POJK No. 40/2019, berdasarkan ketentuan Pasal 10 yang menyatakan bahwa kualitas kredit ditetapkan berdasarkan faktor penilaian yaitu prospek usaha, kinerja debitur dan kemampuan membayar. Setelah berlakunya POJK No. 11/2020 juncto POJK No. 48/2020, penilaian kualitas kredit yang terdiri dari 3 (tiga) faktor berkurang dengan menjadi 1 (satu) faktor, yakni dari kemampuan membayar debitur. Hal ini tercantum dalam Pasal 3 ayat (1), yang menyatakan bahwa penetapan kualitas aset berupa kredit bagi debitur yang terkena dampak penyebaran Covid-19 termasuk debitur usaha mikro, kecil, dan menengah dengan plafon paling banyak Rp10.000.000.000,- (sepuluh miliar rupiah) dapat didasarkan pada ketetapan pembayaran pokok. Mengacu pada ketentuan Pasal 11 ayat (3) huruf a. POJK No. 40/2019 yang menyatakan bahwa penilaian terhadap kemampuan membayar meliputi penilaian terhadap komponen ketepatan pembayaran pokok dan bunga.

Berdasarkan ketentuan pasal-pasal tersebut, dapat disimpulkan bahwa kebijakan stimulus dapat diterapkan kepada debitur yang memenuhi ketepatan pembayaran, agar dapat dilakukan penetapan kualitas aset dan kredit dapat ditetapkan menjadi kualitas lancar. Sehingga, wanprestasi adalah debitur atau debitur yang usahanya terdampak Covid-19, namun sebelumnya sudah memiliki tunggakan kredit. 
Pada prinsipnya, konsep wanprestasi dalam hukum perikatan dan konsep wanprestasi dalam hukum perbankan adalah sama. Pengembalian kredit dengan cara membayar angsuran kredit disebut sebagai prestasi. Apabila debitur tidak membayar lunas utangnya setelah jangka waktu pengembalian tersebut terlewati, maka perbuatannya disebut wanprestasi. Hal ini karena, debitur tidak memenuhi kewajiban atau lalai dalam melaksanakan kewajibannya sesuai dengan kesepakatannya dalam perikatan antara kreditur dengan debitur.

Dalam hukum perikatan, menurut R. Setiawan dalam Gatot Supramono debitur dikatakan wanprestasi yaitu antara lain ketika debitur tidak memenuhi prestasi, dalam perjanjian kredit hal ini terjadi ketika nasabah sama sekali tidak membayar angsuran kredit, kemudian ketika debitur terlambat berprestasi, dalam perjanjian kredit hal ini terjadi ketika nasabah baru membayar kredit setelah jangka waktu yang diperjanjikan berakhir tanpa ada kesepakatan perpanjangan jangka waktu dan ketika debitur melakukan prestasi tetapi tidak sebagaimana yang diperjanjikan yaitu ketika nasabah hanya membayar sebagian angsuran kredit. ${ }^{24}$

Kredit yang dapat diberikan kebijakan stimulus, yaitu kredit yang masih berada pada kualitas Dalam Perhatian Khusus, berdasarkan Lampiran POJK 40/2019 kredit berada pada kategori Dalam Perhatian Khusus apabila terjadi tunggakan hingga 90 hari. Apabila kredit debitur berada dalam kualitas Diragukan hingga Macet, maka telah terjadi tunggakan selama 120 hari hingga 180 hari, yang berarti kredit sudah bermasalah sebelum terjadi pandemi Covid-19. Sedangkan kebijakan stimulus pada POJK No. 11/2020 juncto POJK No. 48/2020 dikhususkan bagi debitur yang mengalami kesulitan pembayaran akibat dampak pandemi Covid-19 secara langsung maupun tidak langsung. Oleh karena debitur tidak memenuhi persyaratan ketepatan pembayaran pokok dan/atau bunga, sehingga tidak dapat dilakukan kebijakan penetapan kualitas aset dan kredit debitur yang bersangkutan masih termasuk dalam kategori kredit bermasalah.

${ }^{24}$ Gatot Supramono, Perbankan Dan Masalah Kredit (Rineka Cipta 2014).[268-267]. 
Kebijakan stimulus berikutnya yaitu debitur dapat mengajukan restrukturisasi kredit. Hal ini tercantum dalam Pasal 5 ayat (1) POJK No. 11/2020 juncto POJK No. 48/2020 bahwa kualitas kredit yang direstrukturisasi ditetapkan lancar sejak dilakukan restrukturisasi. Dalam penjelasan Pasal 5 tersebut dijelaskan bahwa restrukturisasi kredit dapat dilakukan terhadap seluruh kredit kepada debitur yang terdampak Covid-19 tanpa batasan plafon. Terhadap debitur terdampak Covid-19 yang kreditnya telah dilakukan restrukturisasi sebelum POJK No. 11/2020 juncto POJK No. 48/2020 berlaku, bank dapat menetapkan kualitas kredit tersebut menjadi lancar dalam pelaporan akhir bulan.

Pengaturan mengenai restrukturisasi kredit juga diatur dalam Pasal 53 POJK 40/2019, yang menyatakan bahwa Bank hanya dapat melakukan Restrukturisasi Kredit terhadap debitur yang memenuhi kriteria debitur mengalami kesulitan pembayaran pokok dan/atau bunga Kredit dan debitur masih memiliki prospek usaha yang baik dan dinilai mampu memenuhi kewajiban setelah Kredit direstrukturisasi. Ditinjau dari penggunaan kata "dapat", maka ketentuan pasal tersebut tidak bersifat memaksa, sehingga melakukan Restrukturisasi Kredit bukan merupakan kewajiban hukum dari pihak bank. Untuk menentukan apakah debitur telah memenuhi kriteria yang dimaksud dalam Pasal 53 POJK 40/2019, hal tersebut sepenuhnya merupakan kewenangan dan kebijakan dari pihak bank selaku kreditur.

Hal tersebut sesuai dengan Putusan Mahkamah Agung Nomor 2272 K/ Pdt/2015 dalam perkara antara Bank Pembangunan Daerah Jawa Timur, Tbk. cabang Bojonegoro melawan Udy Sanjaya. Dalam perkara tersebut, debitur selaku Termohon Kasasi telah mengalami kredit macet sejak Mei 2010. Bahwa bank telah melakukan penagihan melalui Surat Peringatan hingga diterbitkan Surat Peringatan III pada bulan Oktober 2010. Upaya penagihan tersebut tidak membawa hasil dan tidak ada tanggapan dari pihak debitur. Pada ratio decidendi, Majelis Hakim menentukan bahwa terdapat pembatasan terhadap bank terkait dengan pemberian restrukturisasi kredit. Restrukturisasi kredit harus terlebih dahulu ditolak atau debitur tidak memenuhi persyaratan untuk restrukturisasi kredit, apabila debitur tidak melaksanakan kewajibannya untuk membayar 
tunggakan kredit, debitur tidak beritikad baik atau usaha yang dimiliki debitur dinilai sudah tidak dapat memberikan prospek yang baik.

\section{Prinsip Kehati-hatian dalam Penerapan Pemberian Restrukturisasi oleh Bank}

Hadirnya prinsip kehati-hatian bagi bank dalam menjalankan kegiatan operasionalnya bertujuan untuk memberikan perlindungan hukum bagi masyarakat selaku nasabah bank. Hal ini dikarenakan, sebagian besar permodalan bank berasal dari dana masyarakat sebagai nasabah. Apabila bank dalam aktivitasnya senantiasa menerapkan prinsip kehati-hatian, hal tersebut secara tidak langsung memberikan perlindungan hukum kepada masyarakat sebagai nasabah bank. ${ }^{25}$ Dalam UU Perbankan, prinsip kehati-hatian tercantum dalam beberapa Pasal sebagai berikut:

\section{Pasal 2}

Perbankan Indonesia dalam melakukan usahanya berasaskan demokrasi ekonomi dengan menggunakan prinsip kehati-hatian.

\section{Penjelasan Pasal 8 ayat (1)}

Sebelum memberikan kredit, bank harus melakukan penilaian yang seksama terhadap watak, kemampuan, modal, agunan, dana prospek usaha dari nasabah debitur.

\section{Pasal 29 ayat (2)}

Bank wajib memelihara tingkat kesehatan bank sesuai dengan ketentuan kecukupan modal, kualitas aset, kualitas manajemen, likuiditas, rentabilitas, solvabilitas dan aspek lain yang berhubungan dengan usaha bank dan wajib melakukan kegiatan usaha sesuai dengan prinsip kehati-hatian.

Ketika memberikan kredit kepada calon debitur, bank perlu melakukan analisa kredit terlebih dahulu dengan menerapkan 5 (lima) prinsip yang menjadi bagian dari prinsip kehati-hatian yang dikenal dengan prinsip $5 C^{\prime}$ s, sebagai berikut: ${ }^{26}$

\footnotetext{
${ }^{25}$ Djoni Ghazali dan Rachmadi Usman, Hukum Perbankan (Sinar Grafika 2018).[16-17].

26 Trisadini Prasastinah Usanti dan Nurwahjuni, Pengelolaan Risiko Kredit Dalam Praktik Perbankan (Revka Petra Media 2017).[31-41].
} 


\section{Character (Watak)}

Watak merupakan penilaian utama yang dilakukan bank dengan tujuan untuk mengetahui kejujuran dan itikad baik dari calon debitur sebagai bahan pertimbangan untuk menentukan risiko kredit. Ketika debitur pertama kali mengajukan kredit, bank harus bertatap muka dengan debitur untuk mengetahui ciri-ciri debitur tersebut, kemudian bank melakukan penilaian terkait berbagai informasi mengenai watak calon debitur. Penilaian terhadap watak sangat penting, karena meskipun penilaian kriteria yang lain bagus, tetapi jika hasil penilaian watak kurang baik, besar kemungkinan terjadi kredit bermasalah.

2. Capital (Modal)

Calon debitur yang ingin mengajukan kredit bank harus memiliki modal sebagai uang muka dalam permohonan kredit. Jika calon debitur adalah pengusaha, maka bank harus menganalisis cermat laporan keuangan perusahaan calon debitur untuk mengukur rasio likuiditas dan solvabilitas perusahaan. Apabila semakin banyak modal yang dimiliki perusahaan, maka akan semakin terlihat kemampuannya untuk memenuhi kewajiban.

3. Capacity (Kemampuan)

Bank harus dapat menganalisis kemampuan calon debitur untuk dapat memenuhi kewajibannya dalam perjanjian kredit. Apabila calon debitur adalah seorang Pegawai Negeri/Swasta, maka untuk membuktikan kemampuan calon debitur akan dilihat dari slip gaji yang bersangkutan. Jika calon debitur merupakan pengusaha, bank harus menganalisis kemampuan calon debitur dalam mengelola usahanya sehingga dapat dipastikan bahwa kredit yang akan disalurkan dapat dikelola dengan baik.

\section{Collateral (Agunan)}

Jaminan yang bersifat kebendaan, memiliki tujuan agar memberikan hak verhaal, yaitu hak untuk meminta pemenuhan prestasi kepada kreditur melalui hasil penjualan benda-benda tertentu dari debitur. Oleh karena itu, jaminan yang baik adalah benda yang mempunyai nilai ekonomis yang mudah untuk dijadikan uang. Benda tersebut tetap dapat digunakan kreditur untuk usahanya meskipun 
benda tersebut sebagai jaminan. Dalam rangka memberikan kepastian hukum kepada kreditur, objek jaminan harus dapat dieksekusi pada setiap saat diperlukan oleh kreditur untuk melunasi utang debitur.

5. Condition of economy (Kondisi ekonomi)

Bank juga perlu untuk menganalisis kondisi ekonomi sekarang, sesuai dengan usaha yang dikelola oleh calon debitur serta kondisi ekonomi pada masa mendatang. Selain itu, diperlukan juga analisis terhadap keadaan pasar di dalam maupun di luar negeri apakah dapat mempengaruhi usaha yang dikelola calon debitur, dikarenakan hal tersebut memiliki pengaruh terhadap kemampuan calon debitur untuk memenuhi prestasinya.

\section{Upaya Restrukturisasi Bank Terhadap Debitur Wanprestasi akibat Pandemi Covid-19}

Sebagai upaya penanganan kredit bermasalah akibat pandemi Covid-19, terdapat 2(dua) upaya pokokyang dapat dilakukan bank yaitu upaya penyelamatan kredit dan upaya penyelesaian kredit. Upaya penyelamatan kredit bermasalah bertujuan untuk menyelamatkan dana bank yang tertanam dalam bentuk kredit bermasalah dengan memperhatikan kondisi usaha debitur yang masih mempunyai prospek cukup baik. Dengan dilakukannya upaya penyelamatan tersebut diharapkan memperbaiki kualitas kredit bermasalah menjadi lancar. ${ }^{27}$ Sedangkan, upaya penyelesaian kredit bermasalah dilakukan sebagai upaya terakhir, apabila upaya penyelamatan kredit bermasalah melalui restrukturisasi kredit tidak berhasil dikarenakan beberapa faktor, seperti prospek usaha debitur yang sudah tidak memungkinkan lagi untuk memberikan keuntungan.

Upaya penyelamatan kredit bermasalah dapat dilakukan melalui upaya restrukturisasi kredit, yang meliputi beberapa upaya sebagai berikut: ${ }^{28}$

1. Reschedulling (Penjadwalan Kembali), merupakan upaya yang hanya menyangkut perubahan jadwal pembayaran angsuran serta perubahan jangka

\footnotetext{
${ }^{27}$ Ahmad Subagyo, Teknik Penyelesaian Kredit Bermasalah (Mitra Wacana Media 2015).[85].

${ }^{28}$ ibid.[86-90].
} 
waktu kredit termasuk masa tenggang yang diperlukan. Dalam perubahan ini juga meliputi perubahan terhadap besarnya angsuran. Pengurangan angsuran pokok dan bunga dapat dilakukan dengan cara, antara lain memperpanjang jangka waktu atau periode pinjaman, dan memperpanjang jarak waktu pembayaran angsuran. Dengan upaya reschedulling, diharapkan debitur akan mempunyai waktu yang cukup untuk mengumpulkan modal sehingga dapat mengembalikan kredit dan bunga yang telah dijadwal ulang.

2. Reconditioning (Persyaratan Kembali), merupakan upaya dengan melakukan perubahan sebagian atau seluruh persyaratan kredit yang meliputi jadwal pembayaran, waktu atau persyaratan lainnya seperti penurunan suku bunga atau pembebasan bunga.

3. Restructuring (Penataan Kembali), merupakan upaya penyelamatan kredit yang menyangkut persyaratan kredit, yaitu dengan penambahan dana bank, konversi seluruh atau sebagian tunggakan bunga menjadi pokok kredit baru, dan konversi seluruh atau sebagian kredit menjadi penyertaan modal dalam perusahaan debitur.

Berdasarkan Pasal 1 angka 25 POJK 40/2019, Restrukturisasi Kredit adalah upaya perbaikan yang dilakukan bank dalam kegiatan perkreditan terhadap debitur yang mengalami kesulitan untuk memenuhi kewajibannya. Kemudian, berdasarkan penjelasan Pasal 53 diatur bahwa Restrukturisasi Kredit dilakukan antara lain dengan cara:
a. penurunan suku bunga Kredit;
b. perpanjangan jangka waktu Kredit;
c. pengurangan tunggakan pokok Kredit;
d. pengurangan tunggakan bunga Kredit;
e. penambahan fasilitas Kredit; dan/atau
f. konversi Kredit menjadi Penyertaan Modal Sementara.

Pada penelitian ini, akan dibahas mengenai skema restrukturisasi kredit yang dilakukan oleh PT. Bank Rakyat Indonesia (Persero), Tbk (selanjutnya disingkat Bank BRI). Skema restrukturisasi kredit yang dilakukan oleh Bank BRI 
adalah sebagai berikut: ${ }^{29}$

1. Penurunan suku bunga

Pada awal pemberian kredit, ditetapkan suku bunga sebesar 14\% (empat belas persen) yang harus dibayar efektif tiap bulan. Setelah dilakukan restrukturisasi, suku bunga menjadi:

\begin{tabular}{|c|c|c|}
\hline No. & Periode Bulan & Suku Bunga \\
\hline 1. & Bulan ke $1-3$ & $3 \%$ (tiga persen) p.a, divert $50 \%$ (lima puluh persen) \\
\hline 2. & Bulan ke $4-6$ & $\begin{array}{l}6 \% \text { (enam persen) p.a, divert 30\% (tiga puluh } \\
\text { persen) }\end{array}$ \\
\hline 3. & Bulan ke $7-9$ & $\begin{array}{c}10 \% \text { (sepuluh persen) p.a, divert } 20 \% \text { (dua puluh } \\
\text { persen) }\end{array}$ \\
\hline 4. & Bulan ke $10-12$ & $12 \%$ (dua belas persen) p.a, divert $0 \%$ (nol persen) \\
\hline
\end{tabular}

Debitur pada bulan kesatu sampai dengan bulan ketiga hanya membayar bunga sebesar 3\% (tiga persen), pada bulan ketiga dilakukan divert 50\% (lima puluh persen) yaitu membayar sisa bunga yang belum terbayar dari bulan kesatu sampai dengan bulan ketiga sebesar 50\% (lima puluh persen) dari total keseluruhan bunga. Apabila masih terdapat sisa bunga, sisanya ditunda dan dibayarkan pada akhir periode restrukturisasi.

2. Perubahan penjadwalan angsuran

Jadwal angsuran semula fasilitas kredit sebesar Rp500.000.000,- (lima ratus juta Rupiah) wajib dibayar kembali oleh debitur dengan rincian :

\begin{tabular}{ccccc}
\hline No. & $\begin{array}{c}\text { Tanggal } \\
\text { Mulai }\end{array}$ & Term & Besar Angsuran & Frekuensi Angsuran \\
\hline 1. & $05 / 11 / 2019$ & 6 Bulan & Rp250.000.000,- & 1 \\
2. & $05 / 06 / 2020$ & 6 Bulan & Rp250.000.000,- & 1 \\
\hline
\end{tabular}

Setelah dilakukan restrukturisasi jadwal angsuran menjadi:

\begin{tabular}{cccc}
\hline No. & Periode Bulan & Besar Angsuran Pokok & Frekuensi Angsuran \\
\hline 1. & Bulan ke 1-3 & Rp1.500.000,- & 3 \\
2. & Bulan ke 4-6 & Rp2.000.000,- & 3 \\
3. & Bulan ke 7-9 & Rp5.000.000,- & 3 \\
4. & Bulan ke 10-11 & Rp10.000.000,- & 2 \\
5. & Bulan ke 12 & Rp389.000.000,- & 1 \\
\hline
\end{tabular}

${ }^{29}$ Wawancara dengan Staff Divisi Restrukturisasi dan Penyelesaian Kredit di Bank BRI, pada tanggal 4 Desember 2020. 
3. Perpanjangan jangka waktu kredit

Tanggal jatuh tempo semula fasilitas kredit dengan jangka waktu selama 12 (dua belas) bulan sejak tanggal 01 September 2019 sampai dengan 01 September 2020. Setelah dilakukan restrukturisasi, tanggal jatuh tempo dilakukan perubahan menjadi jangka waktu selama 12 (dua belas) bulan sejak tanggal 01 Mei 2020 sampai dengan 01 Mei 2021.

Restrukturisasi dapat dilakukan dengan kombinasi dari ketiga metode tersebut. Pada prinsipnya, metode restrukturisasi yang diberikan kepada debitur berbeda-beda sesuai dengan kebutuhan dan kondisi cashflow dari debitur yang bersangkutan. Selain ketiga metode tersebut di atas, dapat diterapkan metode restrukturisasi berupa grace period atau penundaan terhadap pembayaran pokok dan/atau bunga selama jangka waktu tertentu, jika berdasarkan analisis dan pertimbangan bank metode tersebut adalah yang dibutuhkan oleh debitur. ${ }^{30}$

Apabila upaya-upaya penyelamatan kredit bermasalah yang dilakukan oleh bank tidak berhasil, maka bank akan melakukan upaya penyelesaian kredit bermasalah dengan melakukan eksekusi terhadap objek jaminan kebendaan atau jaminan perorangan. Apabila bank tidak memiliki jaminan kebendaan maupun jaminan perorangan, maka bank dapat melakukan upaya penyelesaian secara litigasi berupa gugatan melalui pengadilan atau mengajukan permohonan kepailitan. Bank juga dapat melakukan upaya penyelesaian secara non-litigasi melalui penyelesaian sengketa alternatif, misalnya melalui lembaga Arbitrase. ${ }^{31}$

\section{Kesimpulan}

OJK menetapkan kebijakan stimulus berupa pemberian restrukturisasi kredit kepada debitur yang mengalami kredit bermasalah akibat pandemi Covid-19. Maka debitur dinyatakan wanprestasi apabila terjadi tunggakan yang melebihi 90 hari, yaitu kredit yang berada dalam kualitas antara lain, Kurang Lancar,

\footnotetext{
${ }^{30} \mathrm{ibid.}$

${ }^{31}$ Trisadini dan Abdul Shomad (n 5)., Op.Cit.[212].
} 
Diragukan dan Macet. Hal ini disebabkan, debitur tersebut tidak memenuhi persyaratan ketepatan pembayaran pokok dan/atau bunga dalam Pasal 3 ayat (1) POJK No. 11/2020 juncto POJK No. 48/2020, sehingga kredit debitur tidak dapat dilakukan restrukturisasi. Berdasarkan Pasal 5 ayat (1) POJK No. 11/2020 juncto POJK No. 48/2020, bahwa kualitas kredit akan ditetapkan lancar sejak dilakukan restrukturisasi. Oleh karena tidak berhasil direstrukturisasi, maka kualitas kredit tetap dalam kategori kredit bermasalah.

Sebagai upaya hukum bank untuk menangani debitur wanprestasi akibat pandemi Covid-19, dilakukan upaya penyelamatan kredit melalui restrukturisasi kredit. Dalam penelitian ini mengambil contoh skema restrukturisasi pada Bank BRI, yaitu dengan menggunakan metode penurunan suku bunga, perubahan penjadwalan angsuran pokok dan perpanjangan jangka waktu kredit. Apabila restrukturisasi kredit tidak berhasil, maka dilakukan upaya penanganan melalui upaya penyelesaian kredit.

\section{Daftar Bacaan}

\section{Buku}

Ahmad Subagyo, Teknik Penyelesaian Kredit Bermasalah (Mitra Wacana Media 2015).

Djoni Ghazali dan Rachmadi Usman, Hukum Perbankan (Sinar Grafika 2018).

Gatot Supramono, Perbankan Dan Masalah Kredit (Rineka Cipta 2014).

Hermansyah, Hukum Perbankan Nasional Indonesia (Prenadamedia Grup 2014).

Mariam Darus Badrulzaman, Perjanjian Kredit Bank (Citra Aditya Bakti 2008).

Muhamad Djumhana, Hukum Perbankan Di Indonesia (Citra Aditya Bakti 2018).

Purwahid Patrik, Dasar-Dasar Hukum Perikatan (Mandar Maju 1994).

R. Setiawan, Pokok-Pokok Hukum Perikatan (Binacipta 1979).

Rachmadi Usman, Aspek-Aspek Hukum Perbankan Indonesia (Gramedia Pustaka Utama 2001). 
Sudikno Mertokusumo, Mengenal Hukum (Liberty 2007).

Sutan Remi Sjahdeini, Kebebasan Berkontrak Dan Perlindungan Yang Seimbang Bagi Para Pihak Dalam Perjanjian Kredit Bank Di Indonesia (Institut Bankir Indonesia 1994).

Trisadini dan Abdul Shomad, Hukum Perbankan (Kencana Prenanda Media 2017).

Trisadini Prasastinah Usanti dan Nurwahjuni, Pengelolaan Risiko Kredit Dalam Praktik Perbankan (Revka Petra Media 2017).

Yahya Harahap, Segi-Segi Hukum Perjanjian (Alumni 1982).

\section{Jurnal}

Eka Fitri Handayani dan A. Zubaidi, 'Pengaruh Kredit Bermasalah Terhadap Tingkat Profitabilitas Dan Likuiditas Pada Industri Perbankan Yang Terdaftar Di Bursa Efek Indonesia' (2014) 19 Jurnal Akuntansi dan Keuangan.

\section{Tesis}

Dyah Kusumaningrum, 'Pelaksanaan Perjanjian Kredit Yang Diikat Dengan Jaminan Fidusia Di PT. Bank Eksekutif Internasional, Tbk. Cabang Semarang' (Universitas Diponegoro 2008).

\section{Laman}

Nabila Nurul Putri, 'DampakPandemi Corona TerhadapSektorEkonomi Indonesia' (Sukabumi Update, 2020) <https://sukabumiupdate.com/posts/67504/ dampak-pandemi-corona-terhadap-sektor-ekonomi-indonesia> accessed 13 September 2020.

Niken Widya Yunita, 'Penyebab, Asal Mula Dan Pencegahan Virus Corona Di Indonesia' (News Detik, 2020) <https://news.detik.com/berita/d-4956764/ penyebab-asal-mula-dan-pencegahan-virus-corona-di-indonesia> accessed 13 September 2020.

Pipit Ika Ramadhani, 'Jakarta PSBB Lagi, Simak Dampaknya Terhadap Ekonomi' (Liputan 6, 2020) <https://sukabumiupdate.com/posts/67504/dampakpandemi-corona-terhadap-sektor-ekonomi-indonesia $>$ accessed 13 September 2020.

Vincent Fabian Thomas, 'Efek Corona Pada Perbankan: Kredit Dikurangi, Cabang Tutup Temporer' (Tirto Id, 2020)<https:/ / tirto.id/ efek-corona-pada-perbankankredit-dikurangi-cabang-tutup-temporer-fDpN> accessed 13 September 2020. 


\section{Perundang-undangan}

Staatsblad Tahun 1847 Nomor 23 tentang Burgerlijk Wetboek voor Indonesie.

Undang-Undang Nomor 7 Tahun 1992 tentang Perbankan juncto Undang-Undang Nomor 10 Tahun 1998 tentang Perubahan atas Undang-Undang Nomor 7 Tahun 1992 tentang Perbankan (Lembaran Negara Republik Indonesia Tahun 1992 Nomor 31, Tambahan Lembaran Negara Republik Indonesia Nomor 3472).

Peraturan Otoritas Jasa Keuangan Nomor 40/POJK.03/2019 tentang Penilaian Kualitas Aset Bank Umum (Lembaran Negara Republik Indonesia Tahun 2019 Nomor 247, Tambahan Lembaran Negara Republik Indonesia Nomor 6440).

POJK Nomor 48/POJK.03/2020 Tentang Perubahan Atas Peraturan Otoritas Jasa Keuangan Nomor 11/POJK.03/2020 Tentang Stimulus Perekonomian Nasional Sebagai Kebijakan Countercyclical Dampak Penyebaran Coronavirus Disease 2019 (Lembaran Negara Republik Indonesia Tahun 2020 Nomor 267, Tambahan Lembaran Negara Republik Indonesia Nomor 6583).

How to cite: Olga Nadina, 'Wanprestasi pada Kredit Perbankan Akibat Pandemi Coronavirus Disease 2019' (2021) Vol. 4 No. 2 Notaire. 